\title{
The role of commercial real estate to the urban sustainable development
}

\author{
Olga Petrakovska, Yurii Tatsii \\ Kyiv National University of Construction and Architecture, Povitroflotskyi ave. 37, Kyiv 03680, Ukraine
}

\begin{abstract}
Economic reforms in Ukraine continued for 20 years and were accompanied by the development of the land and real estate markets, appearance of new property owners and the formation of new relationships between them. In a market economy fundamentally changing requirements, social and economic mechanisms concerning the regulation of land use. Moreover the reforms are characterized by social and economic stratification of population and as result alteration of needs and interests of different categories and groups of residents. Transitions from a planned to a market economy have totally changed the investment sources too. Most of the objects that address the needs of the urban population or visitors of cities become the profitable real estate and increasingly built on a commercial basis. Dwelling, retail, office and hotel real estate belongs to such objects. Because of the constant reduce of local budgets, commercial real estate begins to play a significant role in the population vital activity, economic and spatial development of cities. Modern technologies allow and facilitate more intensive and complex land use. It is obvious that investor is interested in the use that can bring maximum profit. But great industrialization and concentration of population leads to excessive anthropogenic impact on urban areas and even more often create negative social and environmental stresses.
\end{abstract}

Keywords: commercial real estate; urban sustainable development.

\section{Urban sustainable development and commercial real estate}

Intensive development of free areas has been took place in Ukraine the last 20 years, after the private ownership for land and buildings has been established. Especially attractive are the land plots located in big cities where there are the most favourable conditions for employability and living of the population. Investment value of urban land is not the same across the city and usually changed from the centre to the suburbs. At the heart of the cities and areas close to the centre there is always a shortage on not built up land. Investment value of land depends on whether the land plot meets the requirements that are necessary for the continued successful operation of the property. For commercial real estate the very important factor is the concentration of people as potential consumers of goods and services. In addition the city centres always have a well-developed transport and engineering infrastructure that also increases the desire to develop these areas. Development of urban area aims to improve the living conditions of the population and at the same time to achieve economic results. New construction requires a suitable environment for traffic and transport parking, connection to engineering networks, etc. In the current urban environment it causes difficulties. These difficulties are related with problems faced by the investor, from one side, and with the impact on the environment from new building, from other one.

Investor is interested in the maximization of investment return. Today in Ukraine investment in commercial real estate is carried out by new construction as well as redevelopment of existing buildings. Construction of new buildings leads to increase existing building density. Furthermore the new commercial real estate creates additional pressure on transport and engineering networks, necessary to fine additional space for car parks and so on. Sometimes it is necessary to build new road and to lay new utility networks. It is especially difficult to provide in historical planning structures. All this generally leads to additional anthropogenic load into urban conditions. Important to stress that the sustainable system of land use in the cities on the whole and in its districts is the result of balanced spatial, economic and social connections. A big city is characterized by a large variety of elements that form it. It is expressed by a set of various land use objects that are in interaction with each other and form a certain unity. All these objects work within a balanced system that is permanently transformed. Moreover the use of land for construction in big cities is not limited to the surface and includes overhead and underground space. This in turn further complicates the preservation of the balance of established development areas.

Corresponding author: Yurii Tatsii. E-mail address: valkeru@gmail.com

http://dx.doi.org/10.3846/enviro.2014.129

(C) 2014 The Authors. Published by VGTU Press. This is an open-access article distributed under the terms of the Creative Commons Attribution License, which permits unrestricted use, distribution, and reproduction in any medium, provided the original author and source are credited. 
Existing functional and planning structures have to satisfy certain biological and technological loads and correspond with them. Otherwise thoughtless decisions regarding the construction of new objects lead to deterioration of the living conditions of the population, which is reflected in social tensions, environmental degradation, traffic congestion, worsening of services etc. Just such effects are seen in Ukraine in the last decade in process of building the commercial real estate in centers of large cities.

Challenges facing cities in Ukraine today are largely a result of economic reforms aimed to the development of a market economy and the lack of experience in decision-making in the new socio-economic and legal environment.

Concept of sustainable development as the general concept of present-day reality concerns aims to establish a balance between the needs of the modern appreciation of humanity and protect the interests of future generations, including their need for a safe and healthy environment. The theory and practice of sustainable cities development brings together three elements: economic, social and environmental [1]. Reconciling these different points of view is a very difficult task. The need to achieve environmental, social and economic purposes is given to a situation where some of the goals are achieved through the others A solution of economic problems above social and environmental very often in Ukraine.

In a market economy the construction of an income property is not financed from state and local budgets. Virtually all services such as trade, various office services and hotel services are realized through the formation of commercial real estate. The development of high-quality housing market and provision of dwelling for well-to-do population also carried out mainly on a commercial basis. Only in this way can be satisfied the differences in requirements for housing of different social groups. At the expense of local budget funds is built only housing for socially vulnerable groups of the population. In market conditions Making healthy, entertainment, household needs and others demand of the population are implemented on a commercial basis. Thus commercial property addressing the needs of the population plays a significant role in urban development and as a social dimension of sustainable development.

Commercial real estate market is an essential component of any national economy and organically linked with a number of related markets: labor, finance, building materials, services, etc. [5]. The special place of market of commercial real estate is based on its particularities as the material basis of all human activity and attractiveness as an investment asset.

World experience shows that one of the important items of budget revenues is real estate tax.. In most countries, the tax base is the market value of real estate including cost of land, buildings and other improvement. In Ukraine, there is only a tax on land. The cost of buildings and other improvements in this tax are not included. Adoption of the Law on the tax on commercial real estate in Ukraine can firstly be an important means of filling local budgets, and secondly to reduce the building unreasonably large and complex objects as over ground and underground.

The principles and process of cities development under market economy should be no looking at all participant who are involved in the process and who are ultimate user of the of the property. There is a new activity for Ukraine "development" and a new participant "developer" in the process of urban evolution [8]. Through many years of planned economy and the lack of understanding of the rules of the market the "development" is perceived by the average man as an activity increases the income of the investor only. In reality real estate development is the continual restructuring of the built environmental to meet population's need which is constantly changed according of life style, technologies etc. [4]. In fairness it should be noted that Ukrainian investors also do not think much about sustainable urban environment and its preservation.

In the context of ensuring the concept of sustainable urban development the attitude to commercial real estate should change fundamentally as from population side as from investor.

\section{Analysis of the development of commercial real estate markets in Ukraine}

Today the commercial real estate market is considered one of the most attractive investments in Ukraine. Total foreign investments in commercial real estate in 2012 were approximately 600 million dollars, which is the highest rate in Ukraine for the last 5 years (Fig. 1). Because of political situation in Ukraine in the end of 2013 and in the beginning of 2014 it is very difficult to forecast the foreign investment for the nearest future. But after the stabilization of the political situation in the country the attractiveness of Ukrainian real estate for foreign investors could be resumed.

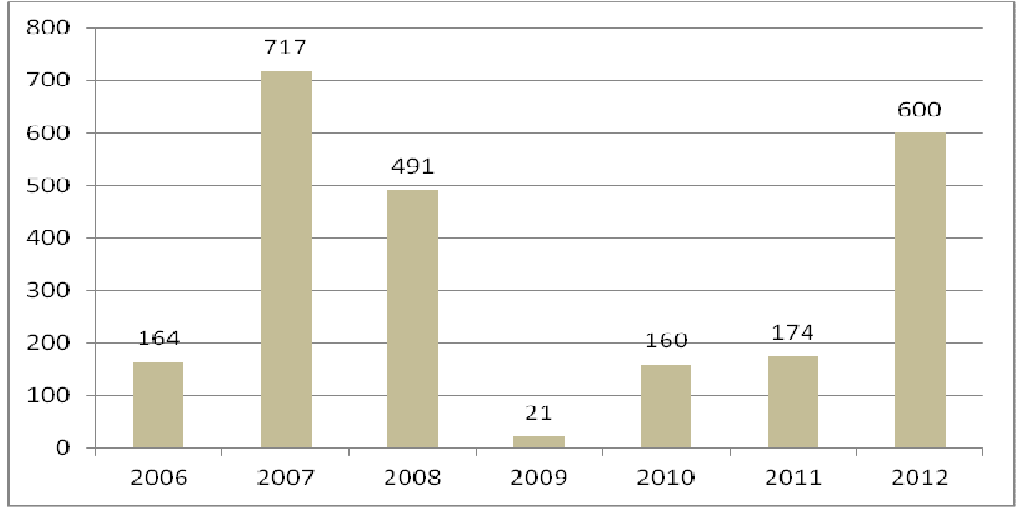

Fig. 1. Foreign investment in commercial real estate in Ukraine, million \$ 
The article is analyzed the most developing markets real estate such as residential, hotel, office and retail real estate. In Ukraine development as type of business is at the beginning of evolution. The origin of Ukrainian development, as a separate kind of business can be attributed to early 2000 when possible purchase and use of property for commercial activities was found legally.

\subsection{Residential real estate}

It is very important to understand the features of residential real estate market in Ukraine. The especial accent should be made on the attitude of residential real estate. Despite the transition to market relations residential real estate is considered as a non-profit because the final consumer gets it for intangible benefits.

Residential real estate could be considered from some viewpoints:

- Basic human need.

- Illustration of social status.

- Goods in the property market.

The first two positions identify market demand. Population with different social status and income has different requirements for housing and this determines the diversity of housing on the market. In most European countries the residential area is 35-45 sq.m. per person. In the former socialist countries (Czech Republic, Hungary, Poland, Slovak Republic, Bulgaria) and post-soviet country (Estonia, Latvia, Lithuania) the living space is less approximately 24-30 sq.m. per person. In Ukraine it is 23 sq.m. per person that does not feat European standards (Fig. 2) [2].

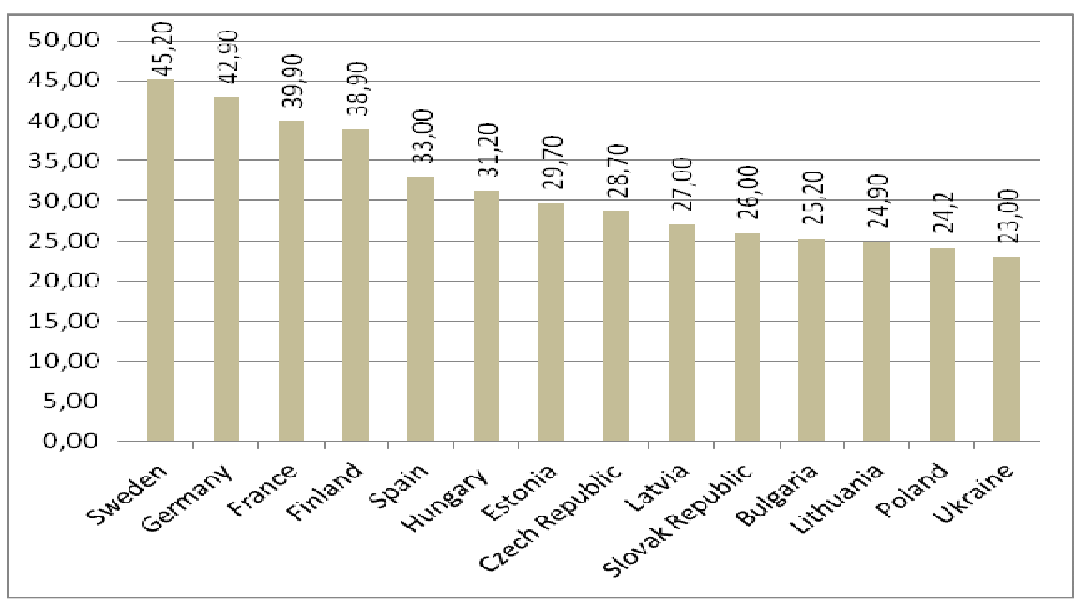

Fig. 2. The average housing provision in different countries (sq.m /residents)

The share of private housing in Ukraine is $93.4 \%$ and $98 \%$ of urban housing are flats in multifamily housing [6]. Development of Residential real estate market directly depends on income of population. The average salary per 1 inhabitant in Ukraine in 2012 was less than 200 euro. The desire and the need to purchase of a new home for most groups of people is not corresponding the incomes.

Changing socio-economic conditions and quality of life in Ukraine for the better will lead to the development of the housing market. Different types of housing are characterized by different requirements for location and different influences on the urban environment.

\subsection{Hotel real estate}

Features of the hotel property lies in the fact that [8]:

- It is for temporary accommodation.

- The demand for hotel real estate is dependent on the development of the country as a whole and of its cultural and business areas and international events.

- The effectiveness of hotels is caused by its location in relation to the objects that generate activity of population.

The effectiveness of the hotel property directly related to the tourism industry. Tourist industry economic indicators ahead of the automotive industry and ranked second after computer. Proceeds from this type of service increased 300 times during the second half of the XX century. The number of tourists in some capitals are illustrated in Figure 3 [6].

Any capital city attracts the largest number of tourists. However, despite the history of Kiev and many historical objects flow of tourists in Kiev is much less than in other capitals. At the same time Ukraine is characterized by the precious of conditions, which estimate tourist attraction. Among them are the following: wealthy natural and climatic conditions, a large number of historical and cultural monuments, visa requirements, etc. However, even with a minimal amount of tourists in Ukraine is not sufficiently developed infrastructure of the tourism business, which implies the existence of different classes and categories hotels. Thus it can be concluded about the existing potential of development hotel market. Demand for hotel services may be increased by both the business tourism and business activities. 


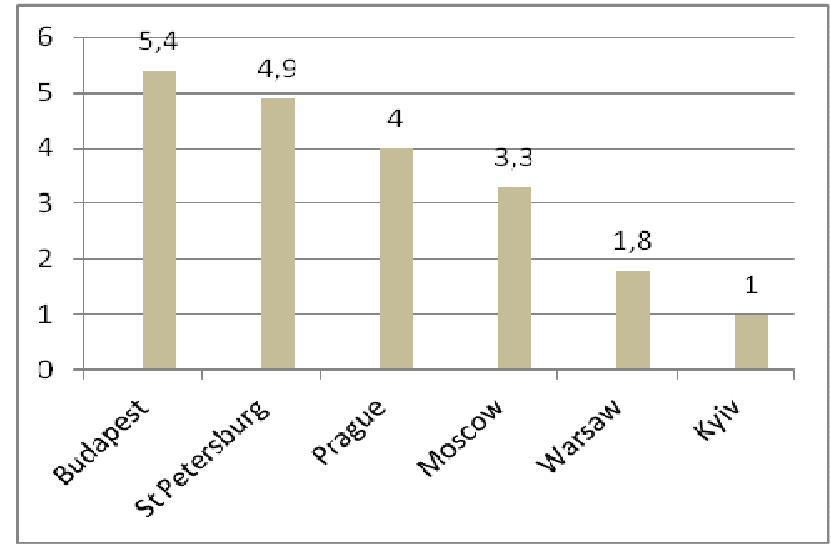

Fig. 3. The number of tourists visiting the city, millions of people a year

\subsection{Office real estate}

Office real estate is the one of the fastest growing segment of the commercial real estate market in Ukraine. The increase in business activity of domestic businessmen and coming to Ukraine and foreign investors caused the need for high quality of office space. The lack of such offices has led to high rents, high return investments in this real estate. The most active development of office market is observed in the big cities of Ukraine and, above all, in Kiev. All that facts can be explained by the high concentration of economic activity in regional centers and especially in the capital.

Comparing the saturation of office areas in Kyiv and other European capitals in Europe illustrate that office space per 1000 inhabitants in Kyiv is much lower than the same indicator in other cities (Fig. 4) [7].

The main demand for high quality offices (that can be classified) during the past two years was formed in almost equal investment by international and domestic companies. The above indicates the prospects of this segment of commercial real estate market. Development of commercial real estate will also help the development of medium and small businesses that provide economic programs of Ukraine.

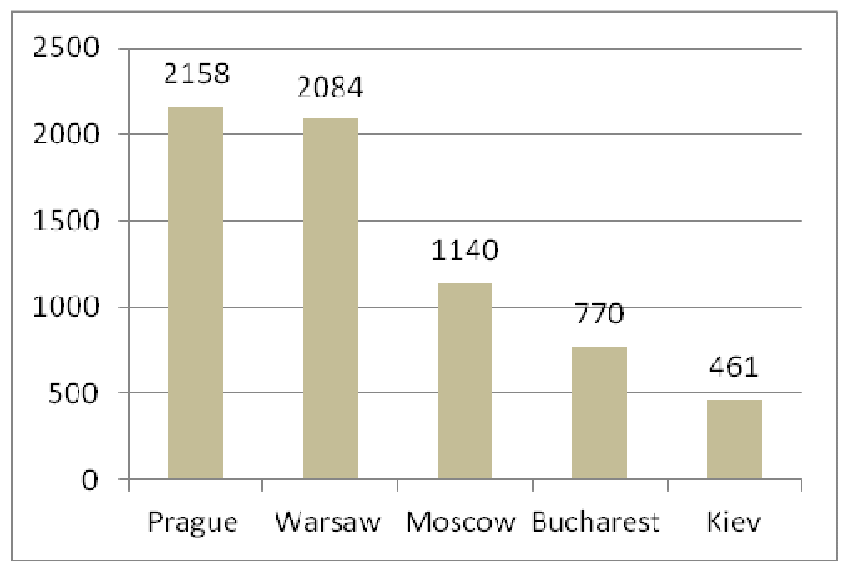

Fig. 4. Availability of office space European cities (sq.m / 1000 residents)

Indicators of employment are a one of the key factors for the office market. However, it should be also taken into account the possibility of migration of business caused by the opening of new industries, the output of new brands in the market, expansion of existing and others. Location of different classes of offices in various parts of the city can be directed to the expansion of services for the population and improve their quality. Also depending on the size of offices and business centers, they can become places of employment.

\subsection{Retail real estate}

The main factor that promotes the active development of retail real estate market is a significant shortage of quality retail space (demand far exceeds supply). In Kyiv saturation quality retail space was 208 square meters per 1000 inhabitants. Compared to the similar indicator in the capitals of Central and Eastern Europe Ukrainian rate is the lowest (Fig. 5) [7]. 


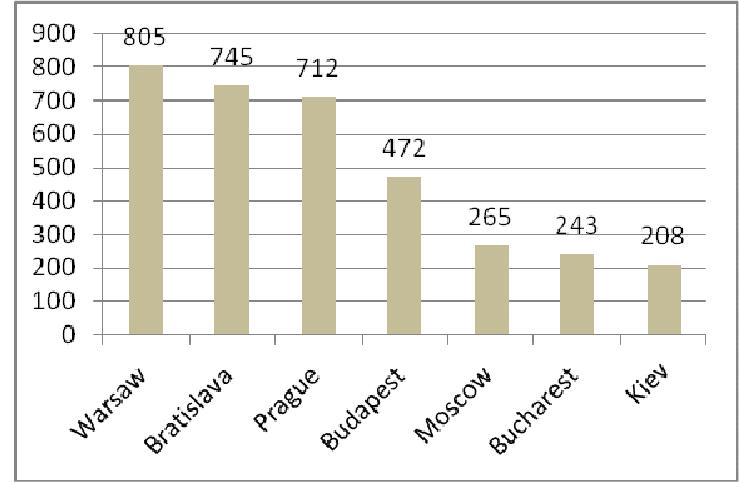

Fig. 5. Availability of retail space European cities (sq.m / 1000 residents)

Meaning of commercial real estate for the population is difficult to overestimate because it is the intermediary between the producers and the consumers of goods (without considering the warehouse property). In large cities such goods as food, clothing, equipment, tools, etc. can be bought mostly there. It is obvious that population income primarily determines a range of required goods and as result the variety of kind of retail objects. But in any case, the need for goods of primary demand is the most constant. The magnitude retail space depends on both the income of the population and of the people quantity in general. Supply of commercial real estate in the different large Ukrainian cities is illustrated in Figure 6.

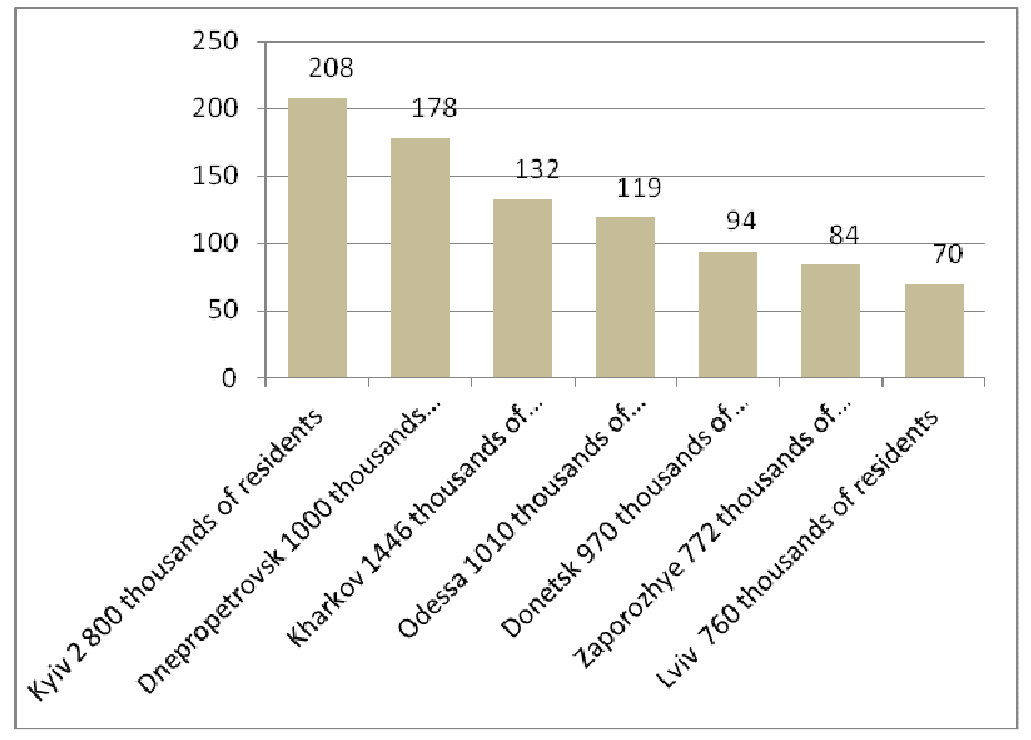

Fig. 6. Availability of quality retail space in large cities of Ukraine (sq.m / 1000 residents)

In reviewing potential development of commercial real estate, it is interesting to consider the structure of expenditures of the average family. The average family in Ukraine spends about 50\% of income on food (including alcohol and tobacco $2.7 \%$ ) and $30 \%$ for non-food goods and services per month. Thus $80 \%$ of the incomes of Ukrainians settle at different stores.

The presented data demonstrate the potential for development of commercial real estate in Ukraine by themselves.

Citizen's needs in goods and services are largely determined by lifestyle and stereotypes that are directly dependent on the size of the city. The larger the city, the brighter stratification of the population in the image and quality of life, and the greater variety of citizen needs. This phenomenon should be considered when analyzing the feasibility of forming commercial real estate. Moreover the population needs are different not only in diverse cities but also in various districts of one city [8].

Given the current state of the commercial real estate markets and the existing realities of their development the authors proposed a new approach to the justification of the need and feasibility of construction of new facilities in existing urban environment as a conceptual model.

\section{Conceptual model of the introduction of commercial real estate in existing urban environments}

The basic principles of sustainable human settlements development [3] and the factors that determine the efficiency of land use for commercial real estate [8] are the basis of model. The model includes two groups of criteria which can provide of efficiency from introduction of commercial objects. The first group is represented by the criteria that evaluate the 
sustainable development of the city. The second one combines the criteria that ensure efficiency and stability of investment in real estate [9].

Taking into account three main components of sustainable development: social, economic and environmental, in the group of factors that must be considered in terms of urban development are encouraged to consider:

- Social interest in the proposed economic activity.

- Ecological security of land use.

- The functional balance of land use in the area.

- Economic feasibility of the introduction of new species of commercial real estate from point of view municipality.

The second group of criteria which directly determine the future stability of commercial properties are represented by:

- The legality of the use.

- Protection of property rights / use.

- Resource potential of land.

- Investment attraction of activity.

Proposed criteria described further.

Social interest in the proposed economic activity shows how the proposed commercial properties is aimed at the interests and needs of different social groups of population to provide goods and services.

Environmental security of land use primarily involves with adherence to environmental legislation for protection, conservation and management of natural resources, health and hygiene requirements for health protection. As well the implementation of measures to prevent the negative impact of land use on the environment has to be included.

The economic feasibility of commercial real estate is manifested in the positive impact that makes the introduction of new real estate in the city's economy and may be valuated by dimension in income to the budgets. Economic efficiency is may viewed in the following main aspects:

- Formation of gross domestic product.

- Tax revenues from economic activity.

- Land taxes.

- Participation in infrastructure development of the city.

It is important to note that today in Ukraine there is no tax for commercial estate. There is only a land tax, which depends on the type of activity and urban values of land. Planning characteristics of the building, such as floors, area etc., not affect the amount of tax. This is one of the reasons why investors are trying to build the largest possible in size building and as result increase revenue. Possible dimensions of the building are defined by the design documentation and existing building norms. Economic efficiency of building size is determined only by the costs of constructing and operating costs. Issue of introduction taxes on property is considered a few years. If such tax is passed, the above list of aspects will include property tax as one of the main components of filling of municipal budgets.

Size of participation in infrastructure development of the city is established by the law of Ukraine and cannot exceed $10 \%$ of the total cost of the construction for non-residential buildings and $4 \%$ - for residential buildings. However, it should be noted that in this case the housing is seen as a non-profit, while in this article, residential real estate is considered as profitable.

Legality of use of land is legally defined by compliance standards, norms, rules concerning the qualitative and quantitative indicators and compliance with rules established by the proposed use planning documentation.

The protection of rights is based on the stability of the legally stipulated procedures guarantee property rights under the terms of the official registration of real estate and rights to it.

Resource potential land accumulates a set of natural, human and economic resources and technological characteristics of the territory and its own planning characteristics that determine the feasibility and optimal use of land. This takes into account not only the current state of the area and the potential variability in the future.

In evaluating the investment attractiveness of the activity in the first place, take into account the social role and importance of services for the population of the city, the level of provision of the services of varying quality, actual and potential output market competition, rate of return and so on.

These criteria are reflected in social, consumer and investment interests that meet the proposed type of real estate. Commercial real estate, which should satisfy those interests, is a category whose essence is expressed in combination of its characteristics as an object of urban environmental, object of rights and business.

The proposed model shows that the feasibility of the location of the commercial real estate and its future performance can be achieved by:

- Combination of requirements that relate to sustainable urban development.

- Consideration of factors which determine the stability of entrepreneurship activity.

- Focus on providing social, consumer and commercial interests.

- Taking into account the characteristics of real estate as an object of urban environmental, object of rights and business. 


\section{Conclusions}

On the results of the article should emphasize the following conclusions:

With the transition to a market economy the land of the city are converted to the product and included in the system of market transactions. In these conditions the commercial land use takes on special significance in ensuring the sustainable development of cities.

The current state of development of markets of residential, hotel, office, retail real estate demonstrates the discrepancy in Ukrainian indices of supply to the same indexes in EU and it has significant potential for development in all sectors and categories.

In the context of present aspects of sustainable urban development the attitude to commercial real estate should be changed by both the population side and investor side fundamentally.

Assessing the feasibility of forming a new property should be based on a combination of requirements for sustainable urban development and contribute to in the stability and reliability of business. The commercial real estate should be considered and evaluated as an object of urban planning, object of right and business.

\section{References}

[1] European Common Indicators. Towards a Local Sustainable Profile. 2003. Ambiente Italia, Milano: Research Institute. 212 p.

[2] Housing Statistics in the European Union. 2010: Available from Internet: http://housing_statistics_in_the_european_union_2010.pdf

[3] Indicators of Sustainable Development: Guidelines and Methodologies. 2007. $3^{\text {st }}$ ed. New York. United Nations. ISBN: ISBN 978-92-1-104577-2. Available from Internet: http://www.un.org/esa/sustdev/

[4] Miles, M. E.; Berens, G. L.; Eppli, M. J.; Weiss, M. A. 2007. Real estate development: principle and process. ${ }^{\text {st }}$ ed. Washington. D.C.: UIL - the Urban Land Institute. 669 p. ISBN 978-0-87420-971-6

[5] Reiser, R. B.; Frej, A. B. 2003. Professional Real Estate Development: The ULI Guide to the business. $2^{\text {st }}$ ed. Washington. D.C.: UIL - the Urban Land Institute. 450 p. ISBN 0-87420-894-7

[6] Соціально-економічний розвиток Украйни'. 2011. State Statistics Service of Ukraine: Available from Internet: http://www.ukrstate.gov.ua

[7] Обзор рынка недвижимости Украины. 2013. Colliers International. Available from Internet: http://www.colliers.com/ru-ua/ukraine/insights/allreports

[8] Петраковська, О. С.; Тацій, Ю. О. 2012. Управління земельними ресурсами Том 5. Сталий розвіток урбанізованих територій. TEMPUS IV. Донецк: УНИТЕХ. 485 с.

[9] Тацій, Ю. Методичні і інформачійні основи визначення оптимального використання земельних ділянок під комериійну нерухомість у мicmax. Summary of PhD thesis. Kyiv. 21 p. 